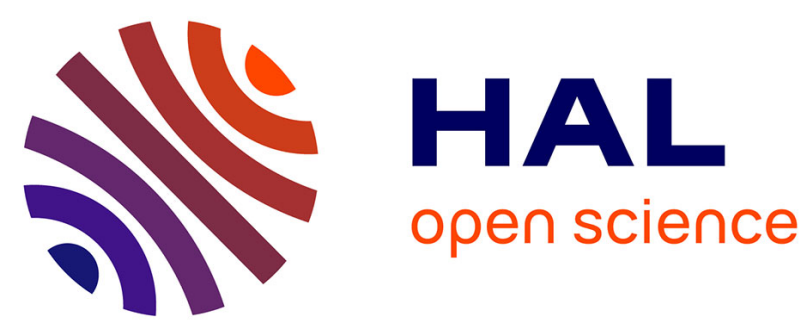

\title{
Design and in vitro studies of a needle-type glucose sensor for subcutaneous monitoring
}

\author{
Dilbir S. Bindra, Yanan Zhang, George S. Wilson, Robert Sternberg, \\ Thévenot Daniel R., Dinah Moatti, Gérard Reach
}

\section{- To cite this version:}

Dilbir S. Bindra, Yanan Zhang, George S. Wilson, Robert Sternberg, Thévenot Daniel R., et al.. Design and in vitro studies of a needle-type glucose sensor for subcutaneous monitoring. Analytical and Bioanalytical Chemistry, 1991, 63, pp.1692-1696. 10.1021/ac00017a008 . hal-01179862

\section{HAL Id: hal-01179862 \\ https://hal.science/hal-01179862}

Submitted on 23 Jul 2015

HAL is a multi-disciplinary open access archive for the deposit and dissemination of scientific research documents, whether they are published or not. The documents may come from teaching and research institutions in France or abroad, or from public or private research centers.
L'archive ouverte pluridisciplinaire HAL, est destinée au dépôt et à la diffusion de documents scientifiques de niveau recherche, publiés ou non, émanant des établissements d'enseignement et de recherche français ou étrangers, des laboratoires publics ou privés. 


\title{
Design and in Vitro Studies of a Needle-Type Glucose Sensor for Subcutaneous Monitoring
}

\author{
Dilbir S. Bindra, Yanan Zhang, and George S. Wilson* \\ Department of Chemistry, University of Kansas, Lawrence, Kansas 66045
}

Robert Sternberg and Daniel R. Thévenot

Laboratoire de Bioeléctrochimie et Analyse du Milieu (LABAM), U.F.R. de Sciences et de Technologie, Université Paris-Val de Marne, Avenue du Gênéral de Gaulle, 94010 Crêteil, Cedex, France

Dinah Moatti and Gérard Reach

Hôtel-Dieu Hospital, Diabetology Department, 1 Place du Parvis Notre Dame, 75004 Paris, Cedex, France

\begin{abstract}
A new miniaturized glucose oxidase based needle-type glucose microsensor has been developed for subcutaneous glucose monitoring. The sensor is equivalent in shape and size to a 26-gauge needle $(0.45-\mathrm{mm}$ 0.d.) and can be implanted with ease without any incision. The novel conflguration greatly facllitates the deposition of enzyme and polymer films so that sensors with characteristics sultable for In vivo use (upper Ilmit of linear range $>15 \mathrm{mM}$, response time $<5 \mathrm{~min}$, and sensitivity ylelding a 5:1 signal-to-background ratio at normal basal glucose levels) can be prepared in high yield $(>60 \%)$. The sensor response is largely independent of oxygen tension in the normal physiological range. It also exhlbits good selectivity against common interferences except for the exogenous drug acetaminophen.
\end{abstract}

\section{INTRODUCTION}

Development of a glucose oxidase based glucose sensor for continuous monitoring of physiological glucose levels was first proposed more than 15 years ago (1). These sensors were incorporated into a macroscopic artificial pancreas and measured diluted blood from an intravenous catheter. Such an arrangement obviously is not practical for ambulatory patient monitoring. Thus, as an alternative, Shichiri proposed the monitoring of glucose in subcutaneous tissue (2). Subsequently, numerous other publications (3-11) have focused on the development of needle-type glucose sensors suitable for subcutaneous monitoring. Several studies $(5,12-14)$ have confirmed that under steady-state conditions the apparent subcutaneous glucose levels are identical with those of blood glucose, thus making this site effective. Also, in a recent paper, it has been demonstrated that it is possible to control plasma glucose in diabetic dogs during a glucose load by using a closed-loop insulin delivery system based on subcutaneous glucose measurement (15). This is in agreement with the demonstrated short lag time between the changes in glucose concentration in subcutaneous tissue and in blood $(4,5)$. Intravascular systems have been shown to function safely in a limited number of diabetic dogs (16).

Several enzymatic glucose sensors $(2,4-9)$ that have been utilized with some success in the past for subcutaneous monitoring of glucose are compared in Table I. As noted, most of the sensors are too large to be suitable for in vivo monitoring if frequent changes of the sensor are required. For such applications, a miniaturized sensor (less than $0.5 \mathrm{~mm}$ in diameter) is needed that can be conveniently implanted by

* To whom all correspondence should be sent.
Table I. Glucose Sensors Used for Subcutaneous Glucose Monitoring

shape

o.d., $\mathrm{mm}$

determinant site

ref

needle type (blunt)

needle type

1.0

needle type

2.5

needle type

1.3

needle type

planar

0.5

0.35

1.0 (width)

$\mathrm{H}_{2} \mathrm{O}_{2}$

$\mathrm{H}_{2} \mathrm{O}_{2}$

dimethylferrocene

dimethylferrocene

$\mathrm{H}_{2} \mathrm{O}_{2}$

$\mathrm{H}_{2} \mathrm{O}_{2}$

2,4
5
6
7
8
9

the patient. A sensor with an outer diameter of less than 0.5 $\mathrm{mm}$ will be acceptable considering that the needles used by diabetics for their daily insulin injections are in the 0.4-mmdiameter range. The fabrication of such devices usually requires the deposition of several layers of polymer and enzyme directly on the sensor. The miniaturization of the sensor, therefore, is not trivial.

The configuration of the sensor is a function of whether the glucose oxidase catalyzed oxidation of glucose is monitored by measuring $\mathrm{H}_{2} \mathrm{O}_{2}, \mathrm{O}_{2}$, or a redox mediator such as dimethylferrocene. All configurations have their advantages and disadvantages. The most successful oxygen-detecting sensor has been developed by Gough and co-workers (16). Because oxygen is monitored, a low applied potential for amperometric detection is required. The potential is in a region where few endogenous electroactive species can interfere. Also, the gas-permeable hydrophobic layer over the electrode prevents access to the electrode surface of small interfering polar species. The signal of merit is the difference between the ambient oxygen level and the level attained as a result of oxygen depletion by the enzymatic reaction. To obtain this differential signal, basal ambient oxygen levels must be assumed constant or must be monitored. The hydrogen peroxide based sensor is more easily fabricated, but it suffers in principle from the poor electrochemical selectivity and the dependence of response on ambient oxygen. These problems can be largely corrected by using semipermeable membranes with specific transport properties. For example, if the ratio of glucose-to-oxygen flux can be decreased, this can result in insensitivity of the sensor response to oxygen tension (17). Suitably designed membranes can also screen out substances that may interfere with the electrochemical response $(18,19)$. Because the reduced enzyme is fairly easy to oxidize, mediators such as ferrocene have been used in place of oxygen as the electron acceptor. Again the applied potential can be in a region where few endogenous electroactive species can interfere. In principle, such a sensor should also show almost complete insensitivity to variations in oxygen tension, but this is not always guaranteed. Oxygen can affect the response indirectly by competing with the mediator for the reduced 


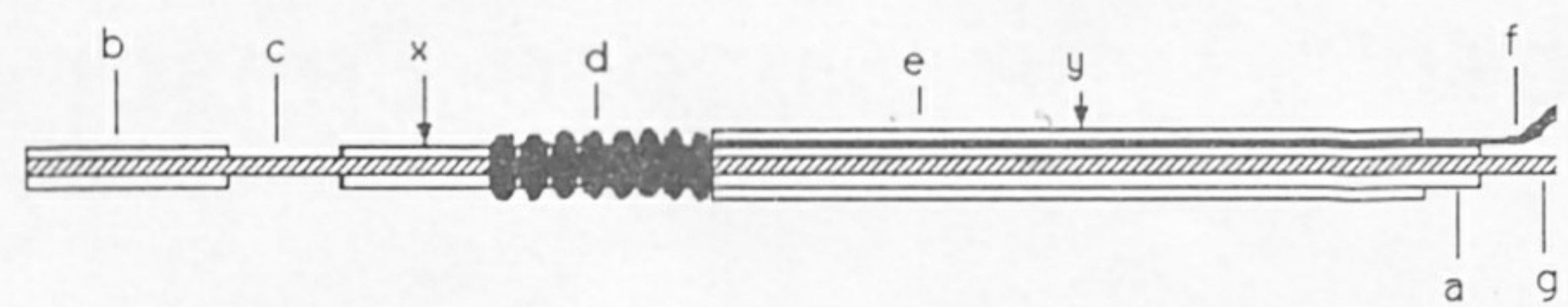

Flgure 1. Schematic diagram of the sensor: (a) Teflon-coated Pt-Ir wire (0.25-mm o.d.), (b) Teflon tip, (c) sensing cavity (1-mm length), (d) $\mathrm{Ag} / \mathrm{AgCl}$ reference electrode, (e) heat-shrinkable tubing, (f) reference electrode terminal, (g) working electrode terminal.

enzyme. These sensors suffer from a lack of long-term stability and possible toxicity of the mediator.

We have designed a needle-type hydrogen peroxide based amperometric sensor equivalent in shape and size to a 26gauge needle (0.45-mm o.d. overall, 0.25 -mm o.d. for sensing portion). The sensing element is located at the side of the sensor in the form of a cavity (Figure 1). A coaxial reference electrode of high surface area is also included. A critical property of the stated geometry is that it permits easy deposition of the several polymeric films, providing uniform performance and better reproducibility of the sensor's final characteristics. The miniature needle shape is a conveinient design for a subcutaneous sensor and is believed to minimize inflammation (20). These sensors have been demonstrated to work reliably for up to 20 days when implanted in the subcutaneous tissue of a rat (21). This paper, however, will deal only with the design and the in vitro evaluation of these sensors. The various factors that can affect the in vivo performance of the sensor such as the influence of temperature and $\mathrm{H}_{2} \mathrm{O}_{2}$ on enzyme stability, $\mathrm{O}_{2}, \mathrm{pH}$ dependence of the response, and selectivity toward possible interferents are better studied in vitro. A thorough understanding of in vitro response is very important for the correct interpretation of the in vivo results.

\section{EXPERIMENTAL SECTION}

Equipment. Amperometry was performed by using a Bioanalytical Systems, Inc. (W. Lafayette, IN), Model LC4A amperometric detector. Current-time curves were recorded on a Kipp and Zonen Model BD 40 strip-chart recorder.

Materials. High-purity glucose oxidase (EC 1.1.3.4) (242000 units/g) was obtained from Biozyme Laboratories International Ltd. (San Diego, CA). Bovine serum albumin (Fraction V, 98-99\% albumin), bovine IgG, and bovine fibrinogen (Type 1-S) were all products of Sigma. Bovine serum was purchased from Hyclone Laboratories, Inc. (Logan, UT), and was diluted to $80 \%$ with phosphate-buffered saline (PBS), pH 7.4, before using.

All buffer solutions were prepared with water from a Barnstead Nanopure II system. PBS, pH 7.4, was prepared from phosphate salts $(0.1 \mathrm{M})$ and sodium chloride $(0.15 \mathrm{M})$ with sodium azide $(0.1$ $\mathrm{g} / \mathrm{L})$ as preservative. A glucose stock solution $(0.5 \mathrm{M})$ was prepared in PBS and was allowed to mutarotate overnight at room temperature. It was subsequently stored at $4^{\circ} \mathrm{C}$. L-Ascorbic acid (Fisher) and L-cysteine (Sigma) solutions were prepared just before use, as they are subject to oxidative decomposition in solution.

Polyurethane (SG 85A) was obtained from Thermedics, Inc. (Woburn, MA). Cellulose acetate (39.8\% acetyl content) was obtained from Aldrich. All solvents used for polymer solutions were of analytical grade. The glutaraldehyde solution used in immobilization process was purchased from Aldrich as a $25 \%$ aqueous solution.

Fabrication of the Sensor. Indicating Electrode. One end of a 10-cm-long Medwire Corp. (Mount Vernon, NY) Tefloncoated platinum-iridium (Pt-Ir) wire $(0.25-\mathrm{mm}$ o.d.) was stripped to form a cavity as shown in Figure 1. This was achieved by first putting a circular cut on the Teflon coating (35- $\mu \mathrm{m}$ thickness) with a standard paper cutter $4 \mathrm{~mm}$ from the tip and then pulling the Teflon out to create a cavity of about $1-\mathrm{mm}$ length. The excess Teflon at the tip was trimmed off with the cutter, and the tip was sealed off with silicone rubber glue (Dow Corning Corp., Midland, MI).

Reference Electrode. The reference electrode was formed on the Teflon surface, $1.5 \mathrm{~mm}$ above the exposed $\mathrm{Pt}$-Ir surface. A thin silver wire (0.1-mm o.d., $15-\mathrm{cm}$ length) was tightly wrapped
A

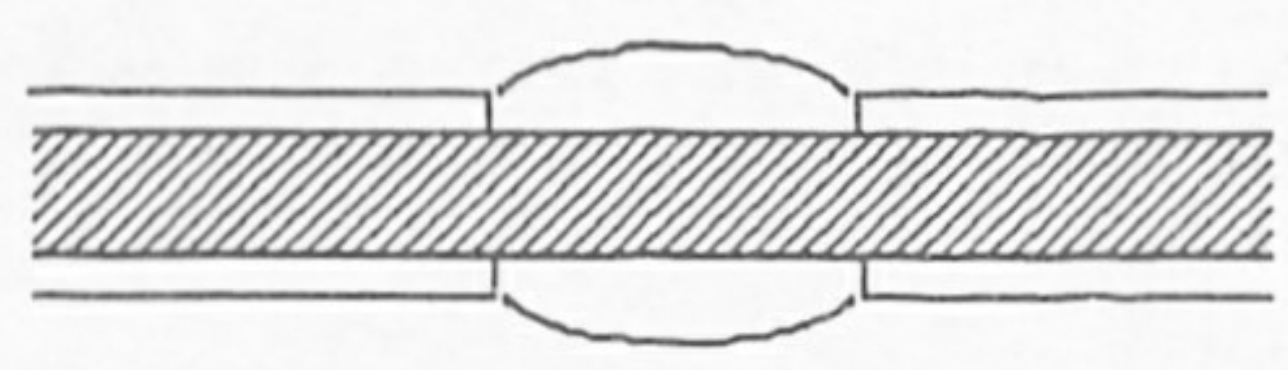

B

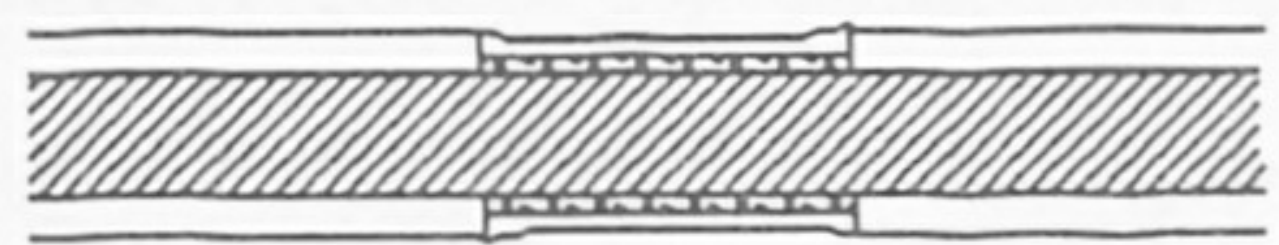

Figure 2. Expanded view of the sensing cavity: (a) cavity holding a drop of enzyme solution; (b) multilayer structure.

around the Teflon surface covering about $4 \mathrm{~mm}$ of its length. A wire wrapping tool (Gardner-Denver) was utilized for this purpose. The straight section above the wrapped silver wire was covered with 5-cm-long, 1.5-mm-o.d. heat shrinkable Teflon tubing (Zeuss Industrial Products, Inc., Raritan, NJ). Protruding lengths of silver wire and Pt-Ir wire were left uncovered for electrical contact. A heat gun (Fisher) operating at $600{ }^{\circ} \mathrm{C}$ was employed for shrinking the Teflon tubing. A layer of silver chloride was formed by passing current $\left(0.4 \mathrm{~mA} / \mathrm{cm}^{2}\right)$ for $60 \mathrm{~min}$ through the wrapped silver wire while it was dipped in a stirred $0.1 \mathrm{~N} \mathrm{HCl}$ solution. The reference electrode was rinsed with deionized water for $6 \mathrm{~h}$. The $\mathrm{Ag} / \mathrm{AgCl}$ reference electrodes prepared in this manner showed potentials of $64 \pm 3 \mathrm{mV}(n=10)$ in $0.15 \mathrm{M} \mathrm{NaCl}$ at $37^{\circ} \mathrm{C}$ vs $\mathrm{Ag} / \mathrm{AgCl}(3 \mathrm{M} \mathrm{NaCl})$.

Enzyme Immobilization. The exposed portion of the Pt-Ir wire acted as the starting point for the construction of the sensing element. The bare surface was first degreased by washing with acetone. It was then rinsed with deionized water and dried in a cold air stream before polymer deposition.

The lower part of the sensor (Figure 1-from arrow $\mathrm{x}$ to the distal end of sensor) was dipped into $5 \%$ cellulose acetate (CA) solution in $50 \%$ acetone $-50 \%$ ethanol for $10 \mathrm{~s}$ and was withdrawn slowly. It was then exposed to the vapor above the CA solution for $5 \mathrm{~s}$ and was dipped again into the CA solution for $10 \mathrm{~s}$. The sensor was removed and dried in air at room temperature $\left(23^{\circ} \mathrm{C}\right)$ for $1 \mathrm{~min}$ and then placed in deionized water for $6 \mathrm{~h}$ to permit displacement by water of entrapped solvent in the membrane pores.

A small volume $(1 \mu \mathrm{L})$ of $\mathrm{GOx}$ solution $(20 \mathrm{mg} / \mathrm{mL}$ in $0.1 \mathrm{M}$ PBS) was held at the tip of a wire (0.5-mm o.d.) in the form of a droplet and was transferred to the sensing element (cavity) simply by moving it through the droplet (Figure 2A). The enzyme solution was allowed to dry for $30 \mathrm{~min}$ at room temperature while holding the sensor horizontally. To immobilize the enzyme, either the sensor was exposed to the glutaraldehyde vapor generated from $0.5 \mathrm{~mL}$ of $25 \%$ glutaraldehyde solution placed at the bottom of an enclosed 4-mL glass bottle for $40 \mathrm{~min}$ at room temperature or a small volume $(1 \mu \mathrm{L})$ of $2 \%$ glutaraldehyde solution was transferred to the cavity and was allowed to react with the adsorbed enzyme for $1 \mathrm{~h}$ at room temperature. The sensor was rinsed thoroughly in deionized water and dried in air for $1 \mathrm{~h}$. With some care, the enzyme deposition can be restricted only to the cavity.

Outer Protective Layer. In order to complete the preparation of the sensor, the whole sensor (Figure 1-from arrow y to the distal end of sensor) was dip coated with $5 \%$ polyurethane (PU) solution in $98 \%$ tetrahydrofuran (THF) $-2 \%$ dimethylformamide (DMF). The PU solution $(10 \mu \mathrm{L})$ was held in a wire loop (2-mm i.d.), and the sensor was passed through the loop lengthwise with the sensing end entering first. This left an apparently uniform polymer film on the sensor (Figure $2 \mathrm{~B}$ ) as viewed by using an optical microscope. The sensor was dried in air for $6 \mathrm{~h}$ at room temperature and then left in $0.1 \mathrm{M}$ phosphate-buffered saline (PBS), $\mathrm{pH} 7.4$, for $72 \mathrm{~h}$ to permit outer membrane conditioning. It was possible to increase the thickness of the PU membrane if the desired linear range was not obtained after the first coating. This was accomplished by repeating the above process.

In Vitro Calibration of the Sensor. The sensor was dipped into a temperature and oxygen tension-controllable cell containing $10 \mathrm{~mL}$ of stirred PBS, pH $7.4\left(37^{\circ} \mathrm{C}\right.$, air-saturated), and a potential of $+600 \mathrm{mV}$ (for hydrogen peroxide detection) was applied between the working and the reference/counter electrodes. The background current was allowed to stabilize for at least $30 \mathrm{~min}$. 
The calibration of the sensor was carried out by adding increasing amounts of glucose (or an interferent) to the stirred buffer. The current was measured at the plateau (steady-state response) and was related to the concentration of the analyte.

The sensors were usually stored in $0.1 \mathrm{M}$ PBS, $\mathrm{pH} 7.4$, at room temperature during the stability studies. However, it was verified that it is also possible to store sensors dry at room temperature. The dry sensors $(n=10)$ usually recovered their original sensitivities and linearities within $2 \mathrm{~h}$ after they were put back into the buffer.

Ethylene Oxide (EO) Sterilization. The sensors were sealed into gas sterilization pouches and were exposed to ethylene oxide gas for $12 \mathrm{~h}$ in a gas sterilizer (Millipore Corp., Bedford, MA). The sensors were left in the pouches until they were needed. In all cases, the sensors were allowed to degas for at least $48 \mathrm{~h}$ to get rid of the adsorbed EO before use. This procedure permits sterilization without loss of sensor performance. These results are described elsewhere (22).

\section{RESULTS AND DISCUSSION}

Sensor Preparation. The CA membranes were formed by using a wet process. Dip-coated membranes were allowed to partially dry in air, after which they were submerged in water to permit displacement of residual solvent. The end product was a water-swollen membrane. The porosity of these membranes was controlled by their water content, which in turn was a function of the concentration of ethanol (nonsolvent pore former) in the casting solution containing CA and acetone $(23,24)$. The membranes prepared from a CA solution in a $50 \%$ acetone $-50 \%$ ethanol mixture with a 1-min drying period prior to their immersion in water showed high permeability and good selectivity against small anions. The hydrogen peroxide to ascorbate response ratio ranged between 3 and 10 (relative response corresponding to $0.1 \mathrm{mM}$ solutions of each), compared to the ratio of unity for a membrane showing no permselectivity. The permselective nature of CA membranes is well-known and has been utilized previously to selectively remove interference from anions such as ascorbate and urate $(18,25)$.

One of the most crucial parts of the sensor fabrication is the design of the semipermeable outer membrane. The outer membrane, if properly selected, prevents degradation of the sensor in the biological environment and also decreases the glucose mass transfer relative to oxygen, leading to increased linearity and insensitivity to fluctuations in oxygen tension (26). Considering the many functions this membrane performs, it is reasonable to assume that a barrier with stable and reproducible transport properties is essential for proper functioning of the sensor. A large variety of membranes has been suggested for this purpose, including poly(dimethylsiloxane) (3), polyurethane $(2,4)$, cellulose acetate $(27)$, and Nafion (28). There is no general agreement on the optimal membrane material. PU was selected for the present work because of its good permeability to oxygen $(29,30)$ and because it has been widely used for implantable devices. A 5\% PU solution was selected to prepare these membranes as it provided the possibility of adding an additional layer if the desired characteristics were not obtained after the first deposit. If the initial deposition results in a membrane that is too thick, the sensor must be discarded. Because of the rapidity of this deposition procedure, it was possible to put down a PU layer without significantiy disturbing the underlying enzyme and CA membranes. Exposure of enzyme to organic solvents for even minutes can cause significant loss of activity. Using this new geometry and the new polymer deposition procedure, it was possible to prepare these sensors at a success rate that was better than $60 \%(n>100)$.

Multilayer Permeabilities. One of the biggest challenges for a hydrogen peroxide based glucose sensor is the elimination of interferences resulting from the presence of electrochemically active physiological compounds. Unfortunately, de-
Table II. Sensor Response for Various Interferents ${ }^{a}$

\begin{tabular}{llll}
\multicolumn{1}{c}{ interferent } & $\begin{array}{c}\text { physiological } \\
\text { concn, }{ }^{b} \mathrm{mM}\end{array}$ & \multicolumn{1}{c}{ bias, ${ }^{c} \mathrm{mM}$} & \multicolumn{1}{c}{ \% error } \\
ascorbic acid & $0.01-0.11$ & $0.18 \pm 0.06$ & $3.3 \pm 1.1$ \\
uric acid & $0.27-0.48$ & $0.35 \pm 0.10$ & $6.4 \pm 1.8$ \\
L-cysteine & $0.03-0.10$ & $0.04 \pm 0.03$ & $0.73 \pm 0.55$ \\
urea & $1.3-4.3$ & $\mathrm{ND}^{d}$ & 0 \\
fructose & $<0.4$ & $\mathrm{ND}$ & 0 \\
acetaminophen & $<0.17$ & $2.5 \pm 0.6(n=3)$ & $45 \pm 10$
\end{tabular}

${ }^{a}$ Results are shown as mean \pm SD for 20 sensors. ${ }^{b}$ Serum levels. ${ }^{c}$ Apparent increase in glucose concentration when interferent is added at physiological maximum. ${ }^{d} \mathrm{ND}$, not detected.

Table III. In Vitro Characteristics ${ }^{a}$ of a Needle-Type Glucose Sensor ${ }^{b}$ parameter

background current, ${ }^{c} \mathrm{nA} / \mathrm{mm}^{2}$

normalized sensitivity, $(\mathrm{nA} / \mathrm{mM}) / \mathrm{mm}^{2}$

response time $\left(T_{90 \%}\right)$, min

\section{value}

$1.3 \pm 0.5$

$2.3 \pm 1.1$

$3.5 \pm 1.0$
${ }^{a}$ Reported for the sensors with upper limit of linear range $\geq 15$ $\mathrm{mM} .{ }^{b}$ Results are shown as mean \pm SD for 20 sensors. ${ }^{c}$ Background currents were recorded after $1 \mathrm{~h}$ of polarization.

tection of hydrogen peroxide requires a rather high applied potential. Any substance that is capable of being oxidized at $+600 \mathrm{mV}$ at a platinum surface may possibly act as an interferent. The list of such compounds normally found in blood serum includes ascorbic acid, uric acid, and cysteine (31). Acetaminophen has also been shown to give significant interferences at physiological levels (32). The subcutaneous levels are not generally known and may differ from those in blood.

One of the functions of the inner membrane covering the platinum anode is to improve electrochemical selectivity of the sensor by discriminating against such interferents. Since both ascorbic acid and uric acid are negatively charged at physiological $\mathrm{pH}$, the presence of a negatively charged membrane such as CA on the electrode surface is very effective in retarding such interferents. The response for various interferents is reported as the bias introduced by their presence on the response of a glucose solution (Table II). The resulting error was the percentage change of the sensor output in response to $5.5 \mathrm{mM}$ glucose, when the concentration of interfering compound was varied from zero to its physiological maximum. This represents the maximum possible error since variation from zero to the maximum level is not normally expected. As seen in Table II, the multilayer structure of the sensor was very effective in minimizing the errors resulting from the presence of most of the endogenous interferences. Errors due to acetaminophen were sizable.

In Vitro Characteristics of the Sensor. The in vitro characteristics of the sensor are given in Table III. Besides being selective for glucose as discussed in the previous section, the sensor response must also be linear or predictable from 1 to at least $15 \mathrm{mmol} / \mathrm{L} \mathrm{(33).} \mathrm{One} \mathrm{of} \mathrm{the} \mathrm{functions} \mathrm{of} \mathrm{the} \mathrm{outer}$ polyurethane membrane is to reduce the flux of glucose to the electrode surface and in turn extend the linear dynamic range. The cost of improved linearity is an increase in response time (which should be less than about 5-6 $\mathrm{min}$ ) and a decrease in sensitivity of the sensor. The sensors with an upper limit of linear range between 15 and $20 \mathrm{mM}$ showed sensitivities between 1.2 and $3.4 \mathrm{nA} \mathrm{mM} \mathrm{mm}^{-1} \mathrm{~mm}^{-2}$. The absolute background currents were low (0.4-1 nA). Thus, the signal-to-background ratio at normal glucose levels $(5.5 \mathrm{mM})$ was between 7 and 10 .

Stability of the Reference Electrode. The stability of the reference electrode is an important consideration during 
Table IV. Effect of Applied Potential on Sensor Response and Background Current

$\begin{array}{cccc}\text { appl potential, }{ }^{a} \mathrm{~V} & \begin{array}{c}\text { sensitivity } \\ \text { to glucose } \\ \mathrm{nA} / \mathrm{mM}\end{array} & \begin{array}{c}\text { background } \\ \text { current, }^{b} \mathrm{nA}\end{array} & \begin{array}{c}\text { response to } \\ \mathrm{H}_{2} \mathrm{O}_{2}, \mathrm{nA} / 0.1 \\ \mathrm{mM}\end{array} \\ 0.32 & 0.52 & -0.1 & 2.5 \\ 0.45 & 0.59 & 0.2 & 3.9 \\ 0.50 & 0.65 & 0.2 & 4.0 \\ 0.60 & 0.65 & 0.4 & 4.0 \\ 0.72 & 0.69 & 1.5 & 3.8\end{array}$

${ }^{a}$ Versus $\mathrm{Ag} / \mathrm{AgCl}, 0.15 \mathrm{M} \mathrm{Cl}^{-}$. ${ }^{b}$ Background currents were recorded after $30 \mathrm{~min}$ of polarization.

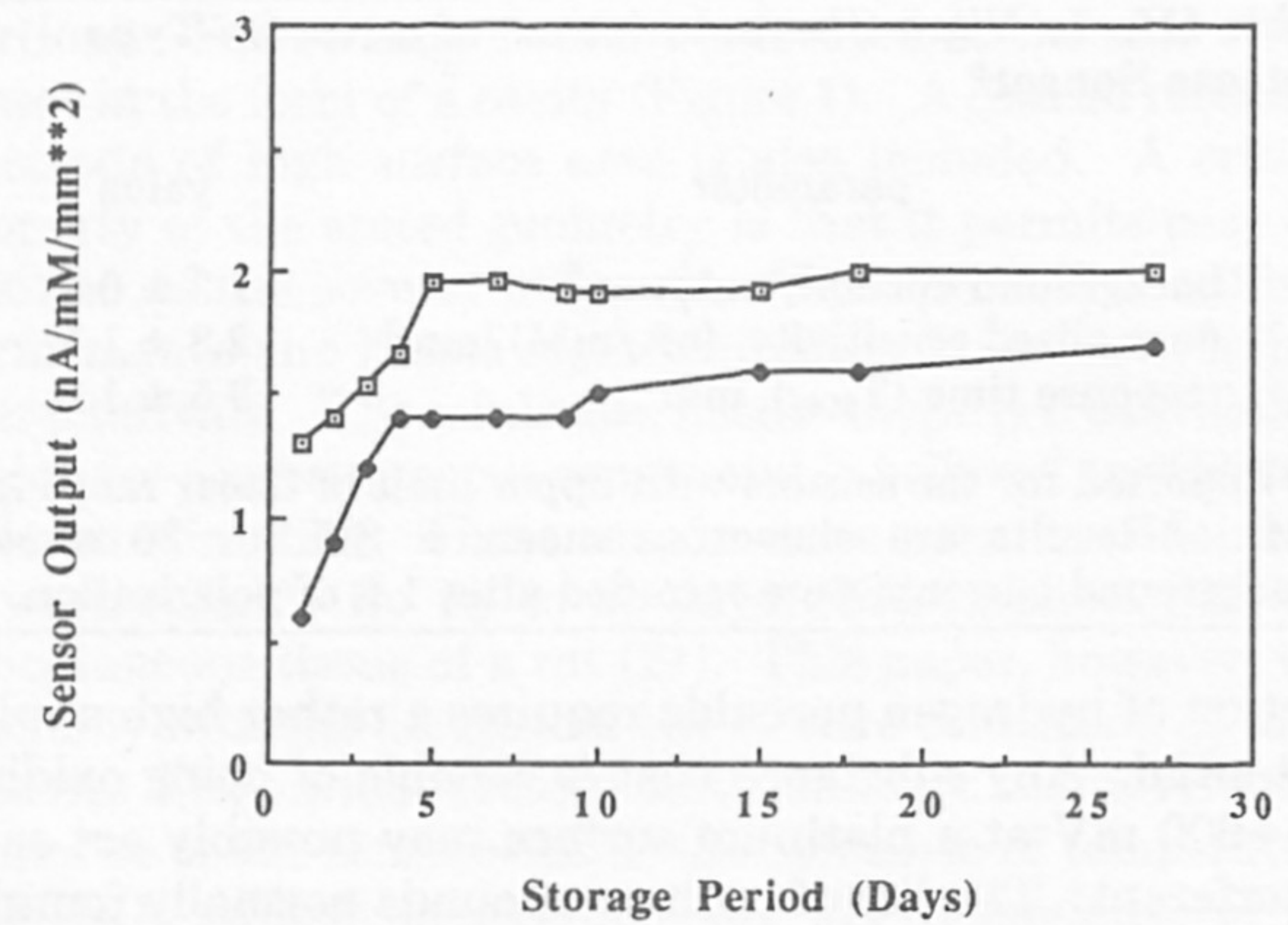

Flgure 3. Storage stability curves for two different sensors. The sensors were stored in $0.1 \mathrm{M}$ PBS, pH 7.4, at room temperature between each calibration.

the in vitro evaluation of a sensor. For a two-electrode amperometric system, a variation in reference potential could cause a change in sensor output depending, of course, on the extent of the variation. There is a possibility that the potential of the reference electrode could change due to flow of current through it.

The potentials of the $\mathrm{Ag} / \mathrm{AgCl}$ electrodes were monitored during the operation of the sensor vs an external standard reference electrode. The variation in potential under normal operating conditions ( $+600 \mathrm{mV}, 37^{\circ} \mathrm{C}, 5.5 \mathrm{mM}$ glucose) was found to be $3 \pm 2 \mathrm{mV}(n=4)$ over a 12 -h period. Considering the fact that the sensor output was almost independent of the applied potential over a wide potential range (Table IV), it was reasonable to assume that such a small variation in the reference potential would not affect the sensor response. As a matter of fact, the drift in sensor output, expressed as a percentage change in the sensor output, to $5.5 \mathrm{mM}$ glucose was found to be only $5 \pm 2 \%(n=4)$ over a 24 -h period. The potential of the reference electrode was also found to be independent of output current in the $0-15 \mathrm{mM}$ range.

Operational and Storage Stability. The storage stability of these sensors was excellent. The polyurethane-coated sensors showed an increase in response (and a corresponding decrease in linearity) for the first few days following preparation before reaching a stable value. This resulted from the swelling of PU membranes as the residual solvents were replaced with water during the conditioning process, increasing their permeability to glucose. Figure 3 shows the results of two typical experiments taken from more than 20 sensors, $80 \%$ of which showed this behavior. The stabilization period was usually between 3 and 7 days. The buffer treatment is also an important step in removing the leachable toxic substances such as residual organic solvents and excess glutaraldehyde from a freshly prepared sensor, thus making the sensor nontoxic (22).

In order to check the operational stability of the sensor, the sensor calibration was run daily over a 7-day period. Between
Table V. Operational Stability of the Sensor ${ }^{a}$

\begin{tabular}{ccccccc}
\multicolumn{7}{c}{ day } \\
\hline 1 & 2 & 3 & 4 & 5 & 6 & 7 \\
4.1 & 4.0 & 4.0 & 4.0 & 4.3 & 4.2 & 4.2 \\
91 & 91 & 91 & 106 & 100 & 91 & 83 \\
14 & 14 & 14 & 14 & 13 & 13 & 13
\end{tabular}

sensitivity to glucose, $(\mathrm{nA} / \mathrm{mM}) / \mathrm{mm}^{2}$ sensitivity to $\mathrm{H}_{2} \mathrm{O}_{2}$ $(\mathrm{nA} / \mathrm{mM}) / \mathrm{mm}^{2}$

linear range, upper limit, mM

${ }^{a}$ Sensor stored continuously in $0.1 \mathrm{M}$ PBS, $\mathrm{pH} 7.4$, containing $5.5 \mathrm{mmol} / \mathrm{L}$ glucose at $37^{\circ} \mathrm{C}$.

each calibration, the sensor was stored in a fresh solution containing $5.5 \mathrm{mmol} / \mathrm{L}$ glucose at $37^{\circ} \mathrm{C}$. No change in sensor response to glucose was observed during this period (Table V). Owing to the storage procedure employed, the enzyme was turning over continuously during the 7-day test. As no potential was applied during the storage period, there was no electrochemical depletion of hydrogen peroxide produced in the enzyme layer. The observed stability of the sensor response under these conditions is quite encouraging because hydrogen peroxide has been reported to denature immobilized glucose oxidase (34). Both the linearity of the sensor and its response to hydrogen peroxide were also maintained (Table $\mathrm{V}$ ), indicating that there was no change in membrane permeability during the test period.

Effect of Temperature and $\mathbf{p H}$. The temperature coefficient was measured by changing the temperature of the test solution from 30 to $42^{\circ} \mathrm{C}$. The output current for $5.5 \mathrm{mM}$ glucose increased by $2.5 \pm 0.6 \%(n=3)$ per $1^{\circ} \mathrm{C}$ increase in temperature. A small variation in body temperature, therefore, during in vivo measurement is not expected to cause a big error in the measurement. The output of the sensor was also found to be stable in the $\mathrm{pH}$ range 7.2-7.8.

Effect of Hydrodynamies and Oxygen Tension. The effect of stirring on sensor output was checked by turning a magnetic stirrer on and off during the sensor calibration. The sensor response was found to be essentially independent of the stirring rate, indicating that diffusion of glucose through the PU membrane is the rate-limiting step rather than the enzymatic reaction. This characteristic of the sensor makes it immune to the external depletion layer effects associated with making measurements in unstirred solutions.

A commonly expressed concern for a glucose oxidase sensor is that changing $P_{\mathrm{O}_{2}}$ levels in the subcutaneous tissue may effect the sensor output. The effect of oxygen tension on the sensor output was checked by equilibrating the test buffer with various air/nitrogen gas mixtures. The oxygen partial pressures were adjusted between 8 and $160 \mathrm{mmHg}$ and were monitored by an oxygen electrode.

For linear sensors (linearity $>15 \mathrm{mM}$ ), the response at 6 $\mathrm{mM}$ glucose was found to be completely independent of the oxygen partial pressure of the test solution in the abovementioned range $(8-160 \mathrm{mmHg})$. Even at the $15 \mathrm{mM}$ glucose level, the difference in sensor output for the two extreme $P_{\mathrm{O}_{2}}$ levels was $3 \pm 2 \%(n=4)$. A nonlinear sensor (linearity $<$ $7 \mathrm{mM}$ ), on the other hand, showed a strong dependence on oxygen tension. Upon decreasing the oxygen pressure from 160 to $8 \mathrm{mmHg}$ at $15 \mathrm{mM}$ glucose, a $35 \%$ decrease in sensitivity was observed. The difference between a linear sensor and a nonlinear sensor (assuming they have similar enzyme loading) is that the linear sensor has a lower sensitivity and its demand for oxygen is, therefore, substantially reduced. In essence, the linearity is obtained by decreasing the glucose flux to the active layer to such an extent that the enzymatic activity far exceeds the substrate (glucose) supply. The overall process is therefore controlled by the diffusion of glucose 
through the outer membrane. Our preliminary estimate of the subcutaneous $P_{\mathrm{O}_{2}}$ levels at the sensor sites in a rat is in the range of $8-25 \mathrm{mmHg}(29)$, which is in agreement with the previously reported (35) values $(23.8 \pm 5 \mathrm{mmHg}, n=16)$. The $P_{\mathrm{O}_{2}}$ of the subcutaneous tissue in man is higher than that found in the rat and is similar to venous $P_{\mathrm{O}_{2}}$ (35). These results indicate that it is possible to design a sensor which is virtually insensitive to changes in oxygen tension in the physiologically relevant $P_{\mathrm{O}_{2}}$ range and also that polyurethane restricts the diffusion of glucose while remaining relatively permeable to oxygen. The above-mentioned results, however, do not predict exactly how the sensor will respond to such low oxygen levels during an in vivo experiment. In vivo experiments are currently underway to clarify this point.

Sensor Testing in Serum. Another important consideration for implantable sensors designed for long-term applications is the sensor stability in the presence of biological fluids.

The sensors were tested in the presence of three major plasma proteins, namely albumin, $\gamma$-globulin, and fibrinogen, which were added to the test buffer at their physiological concentrations. Although the concentration of plasma proteins in interstitial (subcutaneous) fluid is supposed to be low, a higher concentration at the implantation site is possible as a result of tissue/cell damage or as a result of inflammatory processes. None of the proteins showed any effect on the sensor output, even after an extended exposure of the sensor to these proteins for several hours. Though these studies with single proteins are not necessarily representative of the events that might occur in the dynamic physiological environment, we can still conclude that the various sensor membranes were effective in excluding proteins from the electrode surface.

The sensors showed lower sensitivities in serum (bovine) as compared to those in PBS. However, the observed sensitivity values in serum, which were only $70 \pm 3 \%(n=4)$ of the sensitivities in PBS, were stable even after several days of continuous contact of the sensor with serum under sterile conditions. Also, this loss of sensitivity was reversible as the sensors recovered their original sensitivities when tested in PBS after they were removed from the serum and washed with PBS. One possible reason for this loss may be that there are compounds in the serum that adsorb and alter the permeability of the outer membrane. It was quite possible that this adsorption process was initiated by some small compound present in serum, as there was no inhibition from singleprotein solutions. Another possibility might be the inhibition of the electrode surface by small ions or molecules. A recent study, in which an electrochemical sensor was exposed to various fractions of serum as obtained by ultrafiltration, concludes that the removal of large proteins from serum is not enough to completely prevent the poisoning of the sensor (36). These results indicate that a decrease in sensitivity can be expected upon implantation. This underlines the need for in vivo calibration of the sensor and further studies to identify the source of the apparently reversible "inhibition" process.

\section{CONCLUSION}

The performance characteristics of the sensor clearly meet the requirements of an implantable glucose sensor. In addition to the geometry, it is believed that the sensor fabrication techniques also contribute significantly to its sensitivity and stability. The technique involving the use of a wire loop makes possible the application of the same amount of polymer to the sensor each time in what appears to be a film of uniform performance. The sensor geometry is compatible with subcutaneous implantation.

\section{ACKNOWLEDGMENT}

We thank P. Fillatreau for technical assistance.

Registry No. D-Glucose, 50-99-7; glucose oxidase, 9001-37-0; acetaminophen, 103-90-2.

\section{LITERATURE CITED}

(1) Albisser, A. M.; Leibel, B. S.; Ewart, G.; Davidovac, Z.; Botz, C. K.; Zingg, W. Diabetes 1974, 23, 397-404.

2) Shichiri, M.; Kawamori, R.; Yamasaki, Y.; Hakui, N.; Abe, H. Lancet 1982, 2, 1129-31.

(3) Gough, D. A. U.S. Patent 4,671,288, 1987.

(4) Velho, G.; Froguel, P.; Reach, G. Diabetes Nutr. Metab. 1988, 1, 227-233.

(5) Fischer, U.; Ertle, R.; Abel, P.; Rebrin, K.; Brunstein, E.; Hahn von Dorsche, H.; Freyse, E. J. Diabetologia 1987, 30, 940-945.

6) Pickup, J. C.; Shaw, G. W.; Claremont, D. J. Diabetologia 1989, 32, 213-217.

(7) Matthews, D. R.; Bown, E.; Beck, T. W.; Plotkin, E.; Lock, L.; Gosden, E.; Wickham, M. Diabetic Med. 1988, 5, 248-252.

(8) Ege, H. Artif. Organs 1989, 13, 171 (Abs.).

(9) Koudelka, M.; Rohner-Jeanrenaud, F.; Terretaz, J.; Bobbioni-Harsch, E.; de Rooij, N. F.; Jeanrenaud, B. Biomed. Biochim. Acta 1989, 48, 953-956.

(10) Kerner, W.; Zier, H.; Steinbach, G.; Brueckel, J.; Pfelffer, E. F.; Weiss, T. Horm. Metab. Res., Suppl. Ser. 1988, 20, 8-13.

(11) Mascini, M.; Moscone, D.; Palleschi, G. Artif. Organs 1989, 13, 173 (Abs.).

(12) Janle-Swain, E.; Ash, S. R.; Twek, J.; Van Vlerte, J. 33rd Annual Meeting of the American Society of Artificial Internal Organs, New York, 1987; Abstr. 16, p 67.

(13) Bruckel, J.; Kerner, W.; Zier, H.; Steinbach, G.; Pfeiffer, E. F. Klin. Wochenschr. 1989, 67, 491-495.

(14) Jansson, P. A.; Fowelin, J.; Smith, U.; Lonnroth, P. Am. J. Physiol. 1988, 255, E218-220.

(15) Rebrin, K.; Fischer, U.; von Woedtke, T.; Abel, P.; Brunstein, E. Diabetologia 1989, 32, 573-576.

(16) Armour, J. C.; Lucisano, J. V.; McKean, B. D.; Gough, D. A. Diabetes 1990, 1519-1526.

(17) Fischer, V.; Hidde, A.; Herrmann, S.; von Woedtke, T.; Rebrin, K.; Abel, P. Biomed. Biochim. Acta 1989, 48, 965-971.

(18) Palleschi, G.; Rahni, M. A. N.; Lubrano, G. J.; Ngwainbl, N. J.; Gullbault, G. G. Anal. Biochem. 1986, 159, 114-121.

(19) Brazell, M. P.; Kasser, R. J.; Renner, K. J.; Fens, J.; Moghaddam, B.; Adams, R. N. Neurosci. Methods 1987, 22, 167-171.

(20) Woodward, S. C. Diabetes Care 1982, 5, 278-81.

(21) Moatti, D. Unpublished results, 1991.

(22) Zhang, Y.; Bindra, D. S.; Barrau, M. B.; Wilson, G. S. Biosensors Bloelectronics, in press.

(23) Kesting, R.; Barsh, M.; Vincent, A. J. Appl. Polym. Sci. 1965, 9, 1873.

(24) Chawla, A.; Chang, T. J. Appl. Polym. Sci. 1975, 19, 1723.

(25) Sittampalam, G.; Wilson, G. S. Anal. Chem. 1983, 55, 1608-1611.

(26) Ikeda, S.; Aoyama, N.; Ito, K.; Ohkura, K.; Yamamoto, T.; Ichihashi, H.; Kondo, T. Jpn. J. Artif. Organ 1980, 9, 182-192.

(27) Clark, L. C., Jr.; Noyes, L. K.; Spokane, R. B.; Sudan, R.; Miller, M. L. Methods Enzymol. 1988, 137, 68-79.

(28) Harrison, J. D.; Turner, R. F. B.; Baltes, H. P. Anal. Chem. 1988, 60, 2002-2007.

(29) Zhang, Y.; Bindra, D. S.; Wilson, G. S. Unpublished results, 1991.

(30) Tsuchida, T.; Arimatsu, Y.; Yoda, K. Polym. Commun. 1988, 29 (8), 246-248.

(31) Wilson, G. S.; Thévenot, D. R. In Biosensors: A Practical Approach; Cass, A. E. G., Ed.; Oxford University Press: New York, 1990; pp $1-16$

(32) Moatti, D.; Velho, G.; Reach, G. Diabetologia 1990, 33 (Supp.), A117 (Abs.).

(33) Harrison, D. E.; Christie, M. R.; Grey, D. W. R. Diabetologia 1985, 28, 99-103.

(34) Tse, P. H. S.; Gough, D. A. Biotech. Bioeng. 1987, 29, 705-713.

(35) Cater, D. B.; Marina, F.; Silver, I. A. Proc. R. Soc. London, Ser. B $1861,155,136-157$.

(36) Elbicki, J. M.; Weber, S. G. Blosensors 1989, 4, 251-257.

RECEIVED for review September 21, 1990. Accepted May 16, 1991. The support of this work by the National Institutes of Health (DK 30718), Institut National de la Santê et de la Recherche Mêdicale (INSERM), France (CRE 89-90-14), and l'Aide aux Jeunes Diabétiques, France, is gratefully acknowledged. 